\title{
Evaluation of PSHE Online Learning Using SIGUM (Sistem Informasi Guru Mengajar) at State Senior High Schools in Binjai for A.Y 2020/2021
}

\author{
Farid M. Alhumary ${ }^{1, *}$ Suprayitno ${ }^{2}$ Sanusi Hasibuan ${ }^{3}$
}

\author{
${ }^{1}$ Universitas Negeri Medan, Program Magister Pendidikan Olahraga, Medan, Indonesia \\ ${ }^{2}$ Universitas Negeri Medan, Program Magister Pendidikan Olahraga, Medan, Indonesia \\ ${ }^{3}$ Universitas Negeri Medan, Program Magister Pendidikan Olahraga, Medan, Indonesia \\ *Corresponding author. Email: malhumary@gmail.com
}

\begin{abstract}
This study aims to describe the implementation of learning in the PSHE (Physical, Sports and Health Education) Online Learning using SIGUM (Sistem Informasi Guru Mengajar, translate: Teaching Teacher Information System) in Binjai High Schools. This research includes evaluative research which is measured using the CIPP (Context, Input, Process and Product) evaluation model. The samples of this study were the Head of the Education Office, amounting to 1 person, the Principal amounting to 3 people, PSHE teachers totaling 7 people and class XI students totaling 226 people, sampling by random sampling. Data were collected using interviews, questionnaires, and documentation. The data analysis technique used was descriptive analysis technique. The results showed 1. In the context aspect for PSHE teachers respondents obtained $86.53 \%$ and students $82.09 \%$ with policy indicators (Teachers $87.62 \%$, Students $85.13 \%$ ), background indicators (Teachers $82.86 \%$, Students $79.03 \%$ ), goal indicators (Teachers $88.57 \%$, Students $80.58 \%$ ). 2. In the input aspect for PSHE teacher respondents obtained $82.86 \%$ and $71.77 \%$ students with resource indicators (Teachers $85.71 \%$, Students $79.85 \%$ ), information source indicators (Teachers $81.90 \%$, Students $78.50 \%$ ), implementation indicators (Teachers 80.95\%, Students 81.42\%). 3. In the Process aspect for PSHE teachers respondents obtained $78.05 \%$ and students $76.50 \%$ with preparation indicators (Teachers $80 \%$, Students $78.76 \%$ ), implementation indicators (Teachers $77.48 \%$, Students $75.21 \%$ ) . 4. In the Product aspect, PSHE teacher respondents obtained $79.14 \%$ and students $74.10 \%$ with analysis indicators (Teachers $85 \%$, Students $76.02 \%$ ), results indicators (Teachers $73.71 \%$, Students $72.51 \%$ ) . Based on the results of the research obtained, it can be concluded that the implementation of PSHE online learning using SIGUM in Binjai State Senior High Schools is 78.88\% in the "good" category, but still need to be supervised for the smooth implementation of learning.
\end{abstract}

Keywords: Learning Evaluation, Online Learning, PSHE, SIGUM Application.

\section{INTRODUCTION}

Education is important for life, especially the development of the nation and state. As in Law no. 20 of 2003 concerning the National Education System says that the purpose of national education is to develop the potential of students to become human beings who believe and fear God Almighty, have noble character, are healthy, knowledgeable, capable, creative, independent and become democratic citizens and responsible. The statement explains that the purpose of education is to develop the potential of students, namely attitudes, knowledge and skills.
The rise of the corona virus outbreak that has entered Indonesia in early 2020 has so far been more or less a year causing a disease called Covid-19. The Covid-19 that has occurred in various countries including Indonesia has greatly impacted various fields, especially the world of education. In an effort to fulfill the rights of students to continue to receive education services during the emergency spread of Covid-19, the education policy issued by the Minister of Education and Culture Number 3 of 2020 concerning the prevention of Covid-19 in the Education unit and Number 36926/MPK.A/HK/2020 concerning online learning [1], educators are expected to present a fun learning process for students [2]. The Learning from 
Home (LFH) Program in the 2019/2020 Academic Year is carried out through online/distance learning, focusing on meaningful learning experiences for students, without the demand to complete all curriculum achievements for grade promotion and graduation. The BDR program focuses on life skills education, including the Covid-19 pandemic.

Online learning is the use of the internet network in the learning process. Online learning makes students have the flexibility of learning time, can study anytime and anywhere through electronic devices such as cellphones, laptops, computers and so on. So that students can interact with teachers using several applications such as classroom, video conference, telephone or live chat, zoom or through whatsapp groups, especially SIGUM (Sistem Informasi Guru Mengajar, translate: Teaching Teacher Information System). This learning is an educational innovation to answer the challenge of the availability of varied learning resources that can be used in current conditions [3].

SIGUM is a learning application intended for the realm of education, built by the North Sumatra Education Office, Kab. Langkat and the City of Binjai in collaboration with the Medan State Polytechnic (Polmed) launched on June 8, 2020 through a video conference with the Governor of North Sumatra Edy Rahmayadi with the Mayor of Binjai Muhammad Idaham and hundreds of students and high school teachers in Binjai-Langkat against the background of the less than optimal process. teaching and learning during the Covid-19 pandemic which is being used in the current even semester and the previous odd semester. Binjai City is a pioneer for other districts/cities in North Sumatra, so that they can participate in the teaching and learning process using the SIGUM application.

This SIGUM application can provide opportunities for teachers and students to interact as in the teaching and learning process even though it is done online through the provided features such as losters, teacher and student attendance, and quizzes after learning. The teaching and learning process through the SIGUM application can be carried out per each class, where teachers will teach in their classes according to the existing schedule. The principal can also monitor the teaching process. Besides being able to be used for the high school level, the SIGUM application can also be used for the elementary and junior high school levels. The advantages of the SIGUM Application already provide features for students and teachers to take attendance, can access any assignments that have been given with a more organized arrangement, unlimited time and place when carrying out learning, how to correct assignments from students increasingly easy, and if there are students who are left behind in the learning process, then this application can still be accessed and reach anything that has been discussed previously.

So, PSHE learning activities during the Covid-19 pandemic will also continue to be carried out with online learning systems using SIGUM. Sports education is a discipline that is dominated by practice on physical activity and little theory. In line with that, the nature of physical education includes all elements of fitness, physical movement skills, health, games, sports, dance and recreation [4]. In the implementation of PSHE learning with a face-to-face, online and offline system, it must still refer to the content of the educational objectives contained in the Minister of National Education Regulation No. 22 of 2006 [5]. The educational objectives in question include: developing self-management skills in an effort to develop and maintain physical fitness and a healthy lifestyle through selected physical activities and sports. PSHE learning which is dominated by physical movement is carried out in open spaces or in the field. The method for sports education is the deductive method or the command method, with a variety of assignments, demonstrations and a little explanation. Various limitations such as internet access and operational capabilities on online features, physical education naturally encountered various obstacles and obstacles during the Covid-19 pandemic.

For the first time, online learning has been implemented in state high schools throughout the city of Binjai in the 2020/2021 academic year. Therefore, there are still obstacles in achieving optimal learning achievement. This of course has an impact on learning at Binjai High School including PSHE learning that cannot be carried out in accordance with the RPP, many students complain because they have too many assignments, and parents have difficulty in assisting children's learning activities. Physical learning can run successfully and smoothly is determined by several elements including: teachers, students, curriculum, infrastructure, goals, methods, supportive environment, and assessment [6]. If the performance of one of these components has not worked optimally, it will affect the physical education learning program in achieving its goals

Based on the observation results of learning physical education, sports and health in three State Senior High School in Binjai City, namely SMAN 1 Binjai, SMAN 4 Binjai, and SMAN 7 Binjai. As a result of the Covid-19 pandemic, the overall learning system has changed, so that the learning process that starts with conventional or face-to-face changes becomes learning at home which is done online. Likewise, with learning physical education, sports and health.

The author also made initial observations by interviewing several teachers from three state high schools throughout the city of Binjai, namely SMA 
Negeri 1 Binjai, SMA Negeri 4 Binjai and SMA Negeri 7 Binjai. Based on the results of the interview, it is known that learning is less efficient. Due to the habit of face-to-face learning in schools, of course learning online using the SIGUM application needs adjustments. First, the completeness of facilities and infrastructure such as having to have a cellphone or laptop/computer internet management is still independent so that in physical education learning many students complain, are left behind in learning materials, and do not understand the material. Because students have difficulty learning physical education at home which is usually directly practiced at school. Second, the ability of technology and information owned by teachers and students is not optimal, because not all teachers are quick to use this technology in the learning process due to the age factor. As well as online learning for about a year, there has never been an evaluation of physical education learning, especially in Binjai City State Senior High Schools. This evaluation is expected to find out how online learning of physical education in Binjai High School uses SIGUM by looking at the achievement of components in supporting physical education goals.

Evaluation is "an effort to determine the level of implementation of a policy carefully by knowing the effectiveness of each of its components" [7]. Through evaluation, teachers can determine the level of success of the learning process. The success of online learning is influenced by many factors, including: teachers, students, infrastructure, methods, and a supportive environment. If one of these components has not worked optimally, it will affect the PSHE learning program in achieving its learning objectives, therefore to find out the performance of the components that are less than optimal it is necessary to conduct an evaluation. There are several evaluation models, including the evaluation of the CIPP (Context, Input, Process, Product) model developed by Stufflebeam. CIPP evaluation model is carried out systematically to evaluate whether the program has been implemented with the right steps [8]. Evaluation activities cover in terms of context, input, process, product. The evaluation of the CIPP model includes a categorization of system evaluation starting from the view that the success of a program is influenced by several factors [9].

One of the studies on the Effectiveness of Online Learning for PSHE Subjects for Class IX Students at MTs N 2 Semarang During the Covid-19 Pandemic [10], which aims to determine the effectiveness of online learning for PSHE subjects on students. The results show that $98.9 \%$ of online learning sites are located at home using a cellphone via an internet connection with a quota package in a good signal condition. Online learning $56.6 \%$ of students is easy to understand and understand, while Google Classroom is an application that is often used and $61.0 \%$ of students say they understand how to operate online learning media. While giving assignments and exams online $52.2 \%$ of students do not understand and $59.3 \%$ of assignments are many of the obstacles experienced by students. 56.6\% online learning makes students less enthusiastic. It was concluded that online learning as a whole was less effective for PSHE subjects for class IX students at MTs Negeri 2 Semarang during the Covid19 pandemic. Therefore, students expect that the learning system during the Covid-19 pandemic can be done online and also face to face while still complying with health protocols.

Likewise, with the results of research conducted by Sari \& Sutapa [11] which aims to analyze the effectiveness of online learning carried out by SMP Negeri 4 Pakem for the 2019/2020 academic year during the Covid-19 pandemic, the results show that learning Physical Education, Sports and Health (PSHE) with the use of information technology such as Google Classroom running effectively in terms of material understanding, application assignments, and material understanding. The application that is considered the easiest for students to use is Google Classroom. However, there are still weaknesses in learning, namely internet network constraints, lack of physical usefulness from physical learning, and monotonous types of tasks. covers learning motivation and level of understanding of students. The results show that students have the will and self-awareness to actively participate in onlinebased PSHE learning and teachers have tried their best to create proper learning to educate students during the pandemic.

It's been almost a year in 2 semesters, online learning using the SIGUM Application is carried out at State Senior High Schools in Binjai City for the 2020/2021 Academic Year, therefore to find out the success and components that are less than optimal online learning uses SIGUM in physical education needs to be evaluated. Things that need to be evaluated in terms of context, input, process and product. The purpose of this research evaluation is to determine the components of context, input, process, and product in supporting the application of online learning using SIGUM. In addition, it is also necessary to know the obstacles or obstacles faced during the application of online learning using SIGUM so that it can be improved and facilitate the implementation of online learning using SIGUM in the next semester and achieve learning objectives to the fullest.

From the problems above, the researcher wants to evaluate online learning using SIGUM in physical education subjects in Binjai High School which is evaluated using the CIPP model. From the research model, the title of this research is "Evaluation of PSHE Online Learning Using SIGUM in Binjai State Senior High Schools for A.Y 2020/2021". 


\section{RESEARCH METHODS}

This research is classified as an evaluative research. Evaluation research is a research activity to collect data, present accurate and objective information about online learning using SIGUM physical education during the Covid-19 pandemic at State High Schools throughout the City of Binjai. Based on criteria that have been set [7] evaluation is an activity of collecting data or information, to be compared with criteria and then conclusions are drawn. Based on the accuracy and objectivity of the information obtained, it can then determine the value or level of success of the program [12]. The results of the evaluation are used to measure the resulting strength; evaluations for policy makers, managers, and other intended uses; and especially in the use of evaluation information to improve policies and programmes.

This study refers to the CIPP (Context, Input, Process, Product) evaluation model developed by Stuefflebeam at Ohio State University. The CIPP model was chosen because this model is complete enough to evaluate a physical education learning program and makes it easier for researchers to classify program components in the form of context), input, process, and product, not only in the end, but but also until the input and process so that it can interpret data related to the situation, phenomena and results of the implementation of online learning using SIGUM in Senior High School in Binjai City. The CIPP evaluation program belongs in the improvement/accountability category and is one of the most widely applied evaluation models [13].

The design used in this study is a mix method that uses two research approaches at once, namely a qualitative approach and a quantitative approach, which in this study a qualitative approach and is supported by a descriptive quantitative approach. Mix method is a research approach that combines or combines qualitative and quantitative forms [14]. According to Creswell mix method research will be useful if quantitative or qualitative methods are not accurate enough to be used alone in research problems, or by using quantitative and qualitative methods in combination will be able to obtain the best understanding when compared with one method [15].

So this research procedure will produce descriptive data with a quantitative approach used to obtain indepth and comprehensive evaluation results, this approach is used to explain quantitative data (numbers) obtained through research questionnaires. Meanwhile, a qualitative approach was used to obtain information about the description of the implementation of online learning using SIGUM in Binjai High Schools through interviews with teachers and school principals.

According to Suharsimi Arikunto, population is the entire research subject [7] and population is a generalization area consisting of objects/subjects that have certain qualities and characteristics set by researchers to be studied and then draw conclusions [16]. Based on the understanding of the population of the two experts, the population in this study is the Education Office of North Sumatra, Kab. Langkat and the City of Binjai, principals, teachers of physical education, sports and health as well as all students in Binjai High School.

The sample is part or representative of the population being studied [17] and is part of the number and characteristics possessed by the population [16]. The samples to be taken in this study are:

1. North Sumatra Education Office Kab. Langkat and Binjai City, totaling 1 person.

2. Some school principals are limited to 3 people.

3. All physical education subject teachers totaling 21 people.

4. Students of Binjai High School grade XI selected by random sampling technique, namely the technique of determining respondents by being randomly selected without regard to the existing strata in the population [16].

Data collection techniques greatly affect the success of research because data collection is intended to obtain information that can be accounted for and can be trusted. The data collection technique is a tool used by researchers to obtain valid data so that it does not cause doubt. The data needed in this study is in the form of information about the implementation of online learning using SIGUM which can be obtained through several methods and tools. The technique of collecting data in this research is the method of interviews, questionnaires, and documentation. The interview method was used to collect context dimension data while the questionnaire was used to collect input, process, and product dimension data. and documentation as a complement to data collection from all research dimensions in the evaluation process.

The data analysis method used is descriptive statistical analysis method. Descriptive statistics are statistics used to analyze data by describing or describing the data that has been collected as it is without intending to make conclusions that apply to the public or generalizations [15]. After all the data has been collected, the next step is to analyze the data so that a conclusion can be drawn. The data analysis technique used in this study is a descriptive analysis technique, namely describing and interpreting the data from each of the evaluated aspects. After the data is collected, it will be classified into two groups of data, namely quantitative data in the form of numbers, and qualitative data expressed in words. 


\section{RESULTS AND DISCUSSION}

The description of the evaluation data of the PSHE online learning program using SIGUM at State Senior High Schools in Binjai City can be described as follows:

\subsection{Evaluation of Context Aspect}

\subsubsection{The Policy}

The policy of the SIGUM application is based on the results of interviews with the head of the District Education Office Branch. Langkat and the City of Binjai that the application of the SIGUM application is to assist the learning process of teachers and students before online learning as it is now due to the spread of covid-19, this SIGUM application has been planned. However, due to online learning as it is now which causes many obstacles, the plan for implementing SIGUM is accelerated so that it can help the teaching and learning process of online learning during the covid-19 pandemic. So that in June 2020 the SIGUM application was socialized to schools and a comprehensive application began to be made at the end of month 7 , there was socialization to teachers and school principals regarding the use of SIGUM as an alternative made to assist in online learning, schools began to implement it in July- august 2020. On average, schools really appreciate the policy steps that have been made, and each school makes SIGUM application training for their respective students.

Likewise, from the results of interviews with the principal that the school was enthusiastic in responding to the SIGUM application policy, our school followed the online learning policy using the SIGUM application which was implemented in July 2020. The response from the principal after seeing the learning process of the SIGUM application was that the learning application was very complete. and efficient in the implementation of online learning as it is today which can assist teachers in delivering learning materials and assist students in learning to achieve learning objectives.

Likewise, from the results of interviews with PSHE teachers that after participating in SIGUM application socialization and training, teachers use SIGUM in PSHE learning according to policies that have been implemented by the school. The response of the teachers to the SIGUM application is that it is a pretty good application and can make it easier for us teachers to carry out online learning.

\subsubsection{Background}

The background of the SIGUM application is based on the results of interviews with the head of the District Education Office Branch. Langkat and the City of Binjai that the application of the SIGUM application is to be able to assist the online learning teaching and learning process during the covid-19 pandemic, which distinguishes the SIGUM application from many other applications but has the same goal of providing convenience, such as being able to help teachers and students in the process of providing material, schools can monitor the learning process that takes place, and the advantage is that students can attend attendance directly through the SIGUM application, schools also have school operators who help see the learning process taking place, so it can be seen that teachers and students are active in the learning process. The supporting thing in implementing the SIGUM application is that the most important thing is that teachers and students already understand technology, at least these teachers and students are technology literate, already have their own gadgets/PCs and students are also not tech-savvy or technologically stuttering anymore.

Likewise, from the results of interviews with school principals that the reason for schools to carry out online learning using SIGUM during the online learning period is other than the main purpose of preventing the transmission of the Covid-19 virus, and responding to circulars issued by the government and from the Head of the Department of Health. And in this SIGUM application, schools and parents can easily monitor the implementation of learning, and the SIGUM application can make it easier for teachers to deliver teaching materials, attendance, etc., because everything is in one application.

\subsubsection{The Purpose}

The purpose of the SIGUM application is based on the results of interviews with the head of the District Education Office Branch. Langkat and the City of Binjai that the application of the SIGUM application is to create an online teaching application, the point being that teaching and learning activities continue even during the Covid-19 pandemic. And to maximize the online teaching and learning process during the Covid19 pandemic in the following semesters and provide convenience for teachers and students in carrying out online learning. As well as this application as a solution so that even in the midst of this pandemic students can still get access and still get their education rights.

Likewise, from the results of interviews with school principals that the school's goal is to implement the SIGUM application for teachers and students in the online learning process, especially so that the implementation of learning continues to run optimally, and the presence of this application can help teachers manage their learning, and parents can monitor their children in learning. in this application. And the most important thing to achieve the goal is that learning continues to run well and optimally. 


\subsection{Evaluation of Input Aspect}

\subsubsection{Teacher Resources}

Resources in carrying out online learning using the SIGUM application based on the results of interviews with the head of the District Education Office Branch. Langkat and the City of Binjai that the application of the SIGUM application is of course the qualifications of this teacher related to the suitability of the basic education, and it can be said that almost all of the teaching staff in the city of Binjai, especially in high school, the background of the teacher is in accordance with the basic education, as well as supporters of using the SIGUM application such as: gadgets, laptops, and computers.

Likewise, from the results of interviews with school principals that in supporting the implementation of the SIGUM application in online learning, schools provide assistance, such as internet quotas for teachers and students. In order to provide convenience and solutions to the problem of the availability of internet quotas for teachers and students in the online learning process, especially so that the implementation of online learning using the SIGUM application runs smoothly. However, not routinely and only some schools provide internet quota assistance to teachers and students.

Likewise, from the results of interviews with teachers and students that in support of implementing the SIGUM application, teachers and students attend training and understand using SIGUM held by schools. And already have the main tools in using the SIGUM application such as a cellphone or laptop, and internet quota.

\subsubsection{Source of Information}

Sources of information in carrying out online learning using the SIGUM application based on the results of interviews with the head of the District Education Office Branch. Langkat and the City of Binjai that in using the SIGUM application, there are guidelines for its use which are given directly to teachers and students. whole.

Likewise, from the results of interviews with school principals, that in supporting implementing the SIGUM application in online learning, schools have guidelines on how to use SIGUM and schools convey information about guidelines for using SIGUM both to teachers and to students through routine trainings.

As well as the results of interviews from teachers, that in support of implementing the SIGUM application, teachers and students also already have guidelines on how to use SIGUM, the teacher also conveys this information to students who do not really understand how to use the SIGUM application by providing independent guidance, so that it runs with time for now. This average student already understands and understands the use of SIGUM.

\subsubsection{Application}

The application of online learning using the SIGUM application is based on the results of interviews with the head of the District Education Office Branch. Langkat and the City of Binjai that in its implementation provide socialization in the use of the SIGUM application which has carried out several ongoing trainings while still implementing health protocols. In the socialization of the SIGUM application, introducing the SIGUM application and the mechanism of the teaching and learning process in using the SIGUM application which will be carried out per each class where the teachers will teach in their class according to the existing schedule. So, through the SIGUM application, the principal can also monitor and see whether the teacher is teaching or not so that it can be followed up immediately.

The application of online learning using the SIGUM application is based on the results of teacher and student interviews as well as that teachers have also participated in the socialization of SIGUM application trainings carried out in schools and provide guidance to parents and students.

\subsection{Evaluation of Process Aspect}

\subsubsection{Learning Preparation}

The application of online learning using the SIGUM application is based on the results of interviews with the head of the District Education Office Branch. Langkat and Binjai City, that in its application, of course, it is the same as other online learning, such as gadgets/laptops, and internet quotas. As well as students' understanding of the use of the SIGUM application which, if monitored for now, can be said to have understood, because the process of using SIGUM has more or less entered 1 year.

Likewise, from the results of interviews with school principals, that in the preparation given in using the SIGUM application by conducting socialization, schools make student IDs according to students' NISN, and socialize the use of SIGUM, and we also provide internet quota assistance to students. From the socialization and training that has been carried out that the understanding of teachers and students towards the SIGUM application is good, it is added because the school has optimized it by making training on the use of SIGUM to teachers and students, and the implementation process using SIGUM has been running for 3 semesters. 
Likewise, from the results of interviews with teachers, that the preparations made were by preparing all the necessities in the learning process such as lesson plans, materials only, and preparing all the necessities in using SIGUM applications such as gadgets, laptops or computers and most importantly internet quota. As well as the teacher mapping the implementation of learning with competence, planning and estimating the time needed in learning which must still be adjusted to lesson hours, because sometimes the problem is that some students are still not on time in filling attendance and collecting assignments. As well as the results of interviews with students, by preparing the main tools in supporting online learning using the SIGUM application such as gadgets, laptops or computers and most importantly internet quotas. From the results of the interview, it was also found that the average internet network connection at each student's home was supported and some students also used the wifi installed at their home or obtained from other places.

\subsubsection{Learning Process}

Implementation of online learning using the SIGUM application based on the results of interviews with the head of the District Education Office Branch. Langkat and the City of Binjai that in its implementation in the field it has been effectively carried out, whether the use of the SIGUM application in online learning will continue to depend on the online policies issued according to conditions and conditions in the field, the point is that in the future this learning application must be optimized. If learning is no longer carried out online, it is likely that the SIGUM application will still be used to assist the learning process, such as in collecting assignments, etc.

The implementation of online learning using the SIGUM application based on the results of interviews with the principal also that the implementation of online learning using SIGUM is overall good, the response with the presence of the SIGUM application has made learning implementation better, especially during this pandemic, so students still get education in the middle this pandemic outbreak.

Likewise, the implementation of online learning using the SIGUM application based on the results of interviews with teachers also that in the implementation of online learning using SIGUM as a whole it is good, the teacher makes a lot of modifications to learning, one of which is the teacher provides learning videos that are arranged or taken from google or youtube and ask students to analyze and practice the video. The teacher also motivates students to be active in learning, enthusiastic and reprimands students who are not active in the learning process. The assessment is seen from student activity, student discipline in participating in learning, assignments and collecting grades. Because through the SIGUM application, you can immediately provide an assessment of the results of assignments that students do.

Likewise, the implementation of online learning using the SIGUM application based on the results of interviews with students also that in the implementation of online learning using SIGUM students' appearance is sometimes neat, sometimes not if occasionally learning uses video conferences via zoom which always has to be neat otherwise the teacher will be reprimanded directly by the teacher concerned. Facilities and infrastructure for carrying out online learning are also available. Other media used in online learning such as learning video materials and youtube. The students' responses to the online learning process using the SIGUM application have gone smoothly so far because it has been running for 3 semesters, the initial obstacles to using Sigum are gone because they are used to it.

\subsection{Evaluation of Product Aspect}

\subsubsection{Analysis}

Analysis of the implementation of online learning using the SIGUM application based on the results of interviews with the head of the District Education Office Branch. Langkat and the City of Binjai that the SIGUM application is very supportive and appreciates the presence of this application, because it can facilitate the learning process even though online as it is today with the use of SIGUM technology and applications, so we are not technology literate here. Things that need to be addressed may be more about how students are ready to face online learning as it is today so that they remain active and still get their education rights.

Analysis of the implementation of online learning using the SIGUM application based on the results of interviews with the principal also that the application of the SIGUM application to online learning has been effective, because learning using SIGUM as a whole is good. The response with the presence of the SIGUM application has made the implementation of learning better, especially during this pandemic period, so students can still get education in the midst of this pandemic outbreak.

Likewise, the analysis of the implementation of online learning using the SIGUM application based on the results of interviews with teachers that the teacher's response to the SIGUM application is quite satisfied, there are advantages and disadvantages in the application of learning using SIGUM, at least the use of SIGUM keeps students getting education. The difficulties experienced by teachers in implementing the SIGUM application are when giving practical lessons, because PSHE learning contains motion material in a lesson, some students still do not understand and make 
mistakes in making learning material movements, and the delivery of teaching materials is less than optimal compared to face-to-face learning. parents can control the learning carried out by their children, the school is active in viewing and supervising the process of implementing learning using SIGUM, because there are school operators who supervise, so they must be on time in starting and ending learning. The drawback in this application is that it must be more innovative in appearance so that students feel more enthusiastic in carrying out the learning process, and maybe the addition of supporting features such as video confrence and live chat classes so that interaction between fellow students continues. Because students discuss only in the comments for students who do not understand. Actually, this live chat feature is a bit hidden, it's better to show it at the beginning of the display.

Likewise, the analysis of the implementation of online learning using the SIGUM application based on the results of interviews with students that students' responses more or less help online learning. The convenience we feel is being able to take attendance, submit assignments, the teacher provides material and assesses our assignments directly from the SIGUM application, and can be accessed anywhere, the important thing is to have an internet connection and a cellphone/laptop. The problem faced by students is that they do not understand the material given by the teacher, then in the SIGUM application there is no video confrence feature, so when face-to-face learning takes place, it does not use Sigum but other applications. Because online learning is not as effective as face-toface learning and the appearance of the Sigum application lacks still not innovative, there is no video confrencee through sigum, and the sigum must be on time in accessing it, PSHE learning is less effective because PSHE learning has a lot of practical sports material, while this is online, so it's more complicated. The advantages of the Sigum application are that it makes online lessons easier, makes it easier to collect assignments and makes it easier to fill in attendance, and schools and parents can monitor the implementation of ongoing learning.

\subsubsection{Analysis}

The results of the implementation of online learning using the SIGUM application are based on the results of interviews with the head of the District Education Office Branch. Langkat and Kota Binjai stated that the main benefit with the presence of SIGUM is that it can streamline the online learning process and make it easier for teachers to provide teaching materials to students, and also that teachers can control student attendance from the SIGUM application. It can systematically improve the IT skills of teachers and students, and it is also hoped that during online learning using SIGUM can improve the ability of teachers and students to information technology skills. And the strategy that needs to be done to overcome obstacles in the use of the SIGUM application through the principal and his staff must often motivate his students to always be active in online learning using SIGUM, because due to this pandemic the interest of students to learn is reduced, the SIGUM application is actually presented to help teachers in the learning process to be more effective and efficient.

The results of the implementation of online learning using the SIGUM application based on the results of interviews with school principals also that the benefits of the learning process using SIGUM can facilitate the online learning process, starting from attendance, collecting assignments, and schools can control the implementation process which can improve the ability of teachers and students, especially at school. IT skills. The strategy is carried out, by often requiring teachers to motivate their students to stay active in online learning using SIGUM, so that students continue to carry out the learning process.

Likewise, the results of the implementation of online learning using the SIGUM application based on the results of interviews with teachers also that the benefits of students mastering IT more in learning, students are required to analyze a given material, which is expected with that students can better understand teaching materials independently, in using this sigum they can make students also disciplined about time. The most prominent improvement in the application of IT in the world of education and this application can increase the level of student discipline, as well as stand out in motor skills, because students are required to analyze a learning material. The thing that needs to be addressed may be the addition of the video confrencee feature in the SIGUM application so that the process of implementing online learning can be in only one application, and is much more efficient. So students are more motivated and easier to access online learning because everything is already in one application.

Likewise, the results of the implementation of online learning using the SIGUM application based on the results of interviews with students also that the benefits are becoming more IT master and time discipline, the use of SIGUM in PSHE online learning improves student learning outcomes because I always collect assignments and be active in lessons. Things that need to be addressed are the addition of learning support features so that using SIGUM can be more effective.

\section{CONLUSIONS}

Based on the results of evaluative research using interview techniques, questionnaires and documentation carried out in state high schools throughout the city of 
Binjai regarding PSHE online learning using SIGUM some conclusions can be drawn as follows.

\subsection{Based on Context Aspect}

Based on the context aspect regarding the policy indicators applied, the background of the reason for making it, and the purpose of SIGUM, that Binjai High School showed following and implementing online learning using SIGUM and applying it to physical education learning according to the policies that have been set so that Teaching and learning activities continue even though during the Covid-19 pandemic, which was motivated by the lack of maximum teaching and learning processes during the Covid-19 pandemic in the previous semester. And in addition to fulfilling the rights of students to obtain educational services during the emergency spread of Covid-19 and maximizing the online teaching and learning process during the Covid19 pandemic in the following semesters and providing convenience for teachers and students in carrying out online learning.

\subsection{Based on Input Aspect}

Based on the Input aspect of the Resource indicator (Qualification and Competence), sources of information, and application, that supporters in carrying out learning such as teacher resources in Binjai High School already have the minimum qualifications of an appropriate bachelor's graduate, students have their own computers / laptops / smartphones to access SIGUM can also operate computers and smartphone properly, teachers and students participate in online socialization using SIGUM, as well as in online learning training using SIGUM. Information sources for teachers and students in Binjai High School have supported by having guidelines for using SIGUM in carrying out online learning and providing guidance to students regarding online learning using SIGUM. Likewise, students who have prepared the need to carry out PSHE online learning using SIGUM. And the application is that teachers apply online learning instead of school hours and online learning, but teachers do not apply learning strategies to students because it is difficult to apply learning strategies in online learning, especially in PSHE, but due to the online learning system initiatives carried out by teachers by providing material practice in the form of videos or sharing videos that already exist on the internet or youtube for students to learn and practice in their respective homes.

\subsection{Based on Process Aspect}

Based on the aspect of the process indicators of preparation and implementation, that the preparation for implementing PSHE online learning in Binjai High School, the teachers already have prepared annual programs, semester programs, prepared lesson plans, prepared learning media, and distributed learning materials that were in accordance with conditions and access. online learning. Likewise, students who prepare to take part in online learning using SIGUM by preparing all the needs in online learning, previously students were able to operate Sigum on a computer, students could operate Sigum on a smartphone, and students could operate the features in the SIGUM application.

\subsection{Based on Product Aspect}

Based on the aspect of product indicators, analysis and results, the analysis of implementing PSHE online learning using SIGUM in Binjai City State High Schools that teachers and students do not experience difficulties during online learning PSHE uses SIGUM, the SIGUM application is very helpful for teachers during online learning, and the SIGUM application is effective used in the implementation of online learning as it is today. And the results of PSHE's online learning using SIGUM at State Senior High Schools in Binjai City increase student interest in learning, increase student activity, improve student learning outcomes, increase enthusiasm, students have independent learning during online learning using SIGUM, students are motivated to learn, and students do assignments given by the teacher, but the students did not increase their understanding of learning in online learning.

\section{ACKNOWLEDGMENTS}

On this occasion the authors would like to express their sincere thanks and highest appreciation to all those who have helped the author: Mr. Dr. Suprayitno, M.Pd. as the supervisor I and Mr. Dr. Sanusi Hasibuan, M.Kes. as the supervisor II.

\section{REFERENCES}

[1] Kemendikbud. (2020). Surat Edaran Nomor 15 Tahun 2020 tentang Pedoman Penyelenggaraan Belajar dari Rumah dalam Masa Darurat Penyebaran Corona Virus Desease (Covid-19).

[2] Handika, Jeffry dkk. (2020). Pembelajaran Sains Di Era Akselerasi Digital. Magetan Jawa Timur. CV AE Media Grafika.

[3] Nakayama M, Yamamoto H, \& S. R. (2007). The Impact of Learner Characterics on Learning Performance in Hybrid Courses among Japanese Students. Elektronic Journal E-Learning. Vol.5, No. 3.

[4] Qomarrullah, Rif'iy. (2014). Model Aktivitas Belajar Gerak Berbasis Permainan Sebagai Materi Ajar Pendidikan Jasmani (Penelitian Pengembangan Pada Siswa Kelas I Sekolah Dasar). 
Indonesian Journal of Sports Science. Vol. 1, No. 1: 76-88.

[5] Depdiknas. (2006). Kurikulum Tingkat Satuan Pendidikan tahun 2006. Jakarta: Departemen Pendidikan Nasional.

[6] Suryobroto, S Agus. (2004). Diktat Mata Kuliah Sarana dan Prasarana Pendidikan Jasmani. Yogyakarta: FIK-UNY.

[7] Suharsimi Arikunto. (2014). Prosedur Penelitian Suatu Pendekatan Praktis. Jakarta: Rineka Cipta.

[8] Endang Mulyatiningsih. (2012). Metode Penelitian Terapan Bidang Pendidikan. Bandung: Alfabeta.

[9] Mohammad Ali. (2014). Metodologi dan Aplikasi Riset. Jakarta: PT Bumi Aksara.

[10] Nur, Muhammad., Pradipta, Dwi Galih., \& Maliki, Osa. (2020). Efektifitas Pembelajaran Daring Mata Pelajaran PSHE Siswa Kelas XI di Mtsn 2 Semarang Selama Pandemi Covid-19. Seminar Nasional KeIndonesiaan V. Universitas Negeri Semarang. Hal : 108-124.

[11] Sari, Purnama Dyah \& Sutapa, Panggung. (2020). Efektifitas Pembelajaran Jarak Jauh dengan Daring Selama Pandemi Covid-19 Mata Pelajaran Pendidikan Jasmani Olahraga danKesehatan (PSHE). Hal : 19-29.

[12] Newcomer, K. E., Hatry, H. P. \& Wholey, J. S. (2015). Handbook of practicalprogram evaluation: Fourth edition. Published by John Wiley \& Sons, Inc., Hoboken, New Jersey, Canada.

[13] Zhang, W., \& Cheng, Y. L. (2012). Quality assurance in eLearning: PDPP evaluation model and its application. International Review of Research in Open and Distance Learning. Vol 13. No. 3, Hal : 66-82.

[14] Creswell, John W. (2014). Penelitian kualitatif \& Desain Riset. Yogyakarta : Pustaka Pelajar.

[15] Sugiyono. (2013). Metode penelitian manajemen. Bandung: CV Alfabeta.

[16] Sugiyono. (2016). Metode Penelitian Kuantitatif, Kualitatif, dan R\&D. Bandung: Alfabeta.

[17] Suharsimi Arikunto. (2013). Prosedur Penelitian Suatu Pendekatan Praktis. Jakarta: Rineka Cipta. 